\title{
MECHANICAL PROPERTIES OF ROLL EXTRUDED NUCLEAR REACTOR PIPING
}

By

J. M. Steichen and R. L. Knecht

\author{
Westinghouse Hanford Company \\ Richland, Washington
}

January 1975

This report was preparICE

sponsored by the United States an account of work

Research and States nor the United States. Neither

their emplovelopment Administrates Energy

subcontractors, nor any of thion, nor any of

warranty, ers, or their emp their contractors

liability, express or implied loyees, makes any

or usefulness of rensibility for the accurames any legal

process disc of any information accuracy, completeness

infringe privased, or represents, apparatus, product or

fringe privately owned rights.
that its use would not

\section{MASTER}

This paper is based on work performed by the Hanford Engineering Development Laboratory, Richland, Washington, ovorated by Westinghouse Hanford Company, a subsidiary of Westinghouse Electric Corporation, under United States Atomic Energy Commission Contract AT (45-1), -2170. 


\section{DISCLAIMER}

Portions of this document may be illegible in electronic image products. Images are produced from the best available original document. 


\title{
MECHANICAL PROPERTIES OF ROLL EXTRUDED NUCLEAR REACTOR PIPING
}

\section{By}

J. M. Steichen and R. L. Knecht

\begin{abstract}
The elevated temperature mechanical properties of large diameter (28 inches) seamless pipe produced by roll extrusion for use as primary piping for sodium coolant in the Fast Flux Test Facility (FFTF) have been characterized. The three heats of Type $316 \mathrm{H}$ stainless steel piping material used in this study exhibited very consistent mechanical properties and chemical compositions. Tensile and creep-rupture properties exceeded values on which the allowable stresses for ASME Code Case 1592 on Nuclear Components in Elevated Temperature Service were based. Tensile strength and ductility were essentially unchanged by aging in static sodium at $1050^{\circ} \mathrm{F}\left(566^{\circ} \mathrm{C}\right)$ for times to 10,000 hours. High strain rate tensile tests showed that tensile properties were insensitive to strain rate at temperatures to $900^{\circ} \mathrm{F}\left(482^{\circ} \mathrm{C}\right)$ and that for temperatures of $1050^{\circ} \mathrm{F}\left(566^{\circ} \mathrm{C}\right)$ and above both strength and ductility significantly increased with increasing strain rate. Fatigue-crack propagation properties were comparable to results obtained on plate material and no differences in crack propagation were found between axial and circumferential orieritations.
\end{abstract}




\section{INTRODUCTION}

The elevated temperature strength, ductility, corrosion resistance, and long-term metallurgical stability of austenitic stainless steels has led to their extensive use in liquid-metal nuclear reactor systems. Design of these systems often requires that fabrication techniques be developed to produce unique product forms from these materials. One such product form which has been identified is seamless large diameter thin wall piping for primary and secondary heat transport systems. Previous fabrication techniques to produce this type of piping required that extensive machining of extruded blanks be performed to obtain desired diameter and wall thickness. Recently, roll extrusion has been successfully used to produce seamless piping with the desired final dimensions thus eliminating the need for costly machining.

The purpose of this study was to evaluate the mechanical properties of roll extruded primary piping from the Fast Flux Test Facility (FFTF). Results would indicate the quality of roll extruded pipe and would provide material properties data for operations support and safety analysis of the reactor system. The pipe evaluated was seamless Type $316 \mathrm{H}$ stainless steel which was 28 inches $(71 \mathrm{~cm}$.$) in diameter and had a wall thickness of 3 / 8$ inch $(0.96 \mathrm{~cm}$.$) . Detailed descriptions of the selection of the fabrication$ process and material for the FFTF piping have been reported previously[1,2].

The mechanical properties characterization on the pipe material included tensile, creep-rupture, high strain rate, and fatigue-crack growth tests. Although a variety of test temperatures were employed in the evaluation, most tests were performed at the maximum operating temperature of the reactor out- 
let piping $\left(1050^{\circ} \mathrm{F}\right)$. Three heats of piping material were tested to identify heat-to-heat variations. Limited thermal aging (at $1050^{\circ} \mathrm{F}$ for exposures to 10,000 hours) was performed to reveal the effects on the mechanical properties of the piping material.

\section{EXPERIMENTAL PROCEDURE}

Test Material and Specimens

The Type $316 \mathrm{H}$ stainless steel used in this study was obtained from actual 28 irich $(71 \mathrm{~cm}$.) diameter 0.375 inch $(0.96 \mathrm{~cm}$.) wall FFTF primary outlet piping which had been formed by roll extrusion (internal rollers working against a fixed external die). After fabrication the pipe was annealed in air at $1850^{\circ} \mathrm{F}\left(1010^{\circ} \mathrm{C}\right)$ for 45 minutes followed by forced air cooling. The grain size of the pipe material ranged from ASTM 5 to 7 . The chemical compositions of the three heats of material used in this study are presented in Table 1.

Miniature button-head type specimens (Figure 1) were fabricated from the longitudinal forming direction of the pipe and subsequently used for tensile, high strain rate, and creep-rupture testing. Fatigue-crack growth testing was performed on ASTM compact tension specimens[3] which were machined from the pipe as also shown in Figure 1.

\section{Test Procedures}

All tensile and high strain rate tests were performed on hard beam machines. An Instron Tensile Machine was utilized for all tests at a strain rate of $3 \times 10^{-5} \mathrm{sec}^{-1}$, and an MTS Electro-Hydraulic test machine for strain rates from $3 \times 10^{-3}$ to $10 \mathrm{sec}^{-1}$. Both machines were operated at constant crosshead velocity and strain rate values given here are based on the crosshead velocity and initial specimen gauge length. 
TABLE 1. CHEMICAL COMPOSITION OF TYPE 316H STAINLESS STEEL PIPING MATERIAL

\begin{tabular}{|c|c|c|c|c|c|c|c|c|c|c|c|}
\hline & & & & & Comp & tion &.$\% *$ & & & & \\
\hline Heat No.** & Pipe Sample & $c$ & $M n$ & $\mathrm{Ni}$ & $\mathrm{Cr}$ & Mo & $\mathrm{Ti}$ & $P$ & $\mathrm{~s}$ & $\underline{C b}+T_{a}$ & N \\
\hline 55318 & $\begin{array}{l}11085 \text { Z } \\
\text { Check }\end{array}$ & $\begin{array}{l}.046 \\
.057\end{array}$ & 1.87 & 13.60 & 16.70 & 2.38 & 0.02 & 0.015 & 0.012 & 0.01 & $\begin{array}{l}0.088 \\
0.096\end{array}$ \\
\hline 55319 & $\begin{array}{l}11083 \text { Y } \\
\text { Check }\end{array}$ & $\begin{array}{l}.051 \\
.058\end{array}$ & 1.86 & 12.15 & 16.50 & 2.27 & 0.02 & 0.02 & 0.011 & 0.02 & $\begin{array}{l}0.103 \\
0.107\end{array}$ \\
\hline 55320 & $\begin{array}{l}11095 \text { U } \\
\text { Check }\end{array}$ & $\begin{array}{l}.050 \\
.066\end{array}$ & 1.78 & 11.92 & 17.40 & 2.33 & 0.02 & 0.02 & 0.018 & 0.01 & $\begin{array}{l}0.112 \\
0.120\end{array}$ \\
\hline
\end{tabular}


Two methods were used to produce engineering stress-strain curves. For the Instron tensile machine, the output of a conventional strain-gauge load cell was used for determining specimen load and the crosshead displacement for determining specimen extension. Load and displacement values were recorded on a strip chart from which the tensile properties of interest were determined. The MTS Electro-Hydraulic test machine provided load measurement (specimen extension) by a LVDT on the actuator. Voltage outputs from the load cell and LVDT were recorded with a digital data recorder and then translated to load and displacement data. Ductility values reported in this paper were obtained from pre- and post-test specimen measurements. A11 elevated temperature tensile and high strain rate tests were conducted ir. air within recommended ASTM practice.

Constant load creep-rupture tests were performed in an argon atmospriere within recormended ASTM practice. Specimen extension during each test was monitored by measuring pull-rod motion with a precision dial indicator, and the data were plotted as a conventional strain.time curve. Elongation at rupture and reduction of area values raported for each creep-rupture test were determined from pre- and post-test specimen measurements.

All fatigue-crack growth testing was performed in air on an MTS tesi machine using load as the control parameter. A Cyclic frequency of $40 \mathrm{cpm}$ $(0.667 \mathrm{~Hz})$ was used for all tests. Crack lengths were read periodically during each test with a cathetometer. The crack growth rate (da/dN) was calculated by dividing a given crack increment, $\Delta a$, by the number of fatigue cycles in that increment, $\Delta N$. The stress intensity factor $(K)$ was calculated from the standard ASTM formula [3]. Detailed test procedures and test results for the fatigue-crack growth testing of the FFTF piping material have been previously reported by James [4]. 


\section{RESULTS}

Tensile and High Rate Properties

The effect of test temperature and strain-rate on the tensile properties of the subject material have been determined. Tensile results were obtained at a strain rate of $3 \times 10^{-5} \mathrm{sec}^{-1}$ at temperatures from room temperature to $1400^{\circ} \mathrm{F}\left(760^{\circ} \mathrm{C}\right)$. High strain rate testing was performed at temperatures 900,1050 , and $1200^{\circ} \mathrm{F}\left(482,566\right.$, and $\left.649^{\circ} \mathrm{C}\right)$ to a rate of $10 \mathrm{sec}^{-1}$. Although three heats of piping material were used in this study, most testing was performed on one heat of material-(55320). Limited testing on the other two heats (55318 and 55319) was performed to indicate heat-to-heat variations. Results of each test included the proportional elastic limit (PEL), $0.2 \%$ yieid strength and ultimate strengths, total and uniform elongation, and reduction of area. Tabulated data for the completed tests have been reported previously[5].

\section{Tensile Behavior}

The effect of test temperature on the ultimate and $0.2 \%$ yield strengths of the pipe material for a conventional test rate $\left(3 \times 10^{-5} \mathrm{sec}^{-1}\right)$ is illustrated in Figure 2. Included in the figure are curves from G. V. Smith [6] which indicate the minumum and mean uitimate and $0.2 \%$ yield strengths to be expected for the subject material at the various test temperatures. Data obtained from tests on the three heats of piping material are represented by symbols. These data show that for temperatures to $1100^{\circ} \mathrm{F}\left(593^{\circ} \mathrm{C}\right)$ the ultimate strength exceeds the mean behavior of $316-316 \mathrm{H}$ stainless steel. At higher test temperatures convergence with minimum behavior is noted. For all test temperatures the $0.2 \%$ yield strength of the piping material is essentially equal to the mean behavior as described by $G$. V. Smith. As with the ultimate strength, only 
minor heat-to-heat variations on the $0.2 \%$ yield strength are observed.

Figure 3 shows the influence of temperature on the ductility (total and uniform elongation and reduction of area) of the piping material. Both total elongation and reduction of area slightly decrease with temperature to a temperature of $1050^{\circ} \mathrm{F}\left(566^{\circ} \mathrm{C}\right)$ and then rapidly increase with increasing test temperature; uniform elongation (elongation at maximum load) slightly decreases with temperature to $1050^{\circ} \mathrm{F}\left(566^{\circ} \mathrm{C}\right)$ and then rapidly decreases with increasing temperature. Similar trends were observed for the other two heats of piping. Ductility values for the piping material are in agreement with those presented by G. V. Smith [7] for $316-316 \mathrm{H}$ stainless steel. At $1050^{\circ} \mathrm{F}$ $\left(566^{\circ} \mathrm{C}\right.$ ) the total elongation of the piping material was $\sim 44 \%$ and the mean value from $G$. V. Smith was $245 \%$.

Although the ultimate strength is slightly higher, the $0.2 \%$ yield strength and ductility of the roll extruded piping material appear to be comparable to mean behavior of Type $316-316 \mathrm{H}$ stainless stee1. The higher to be ultimate strength is not believed the result of roll extrusion but the result of nitrogen in the test material. The chemical compositions for the three heats of test material (Table 1) indicate they contain high levels of nitrogen ranging from about 0.09 to 0.12 weight percent. Normal austenitic stainless steel melt practice results in nitrogen levels from one-tenth to one-third that observed in the piping material.

Studies on the influence of nitrogen on the tensile properties of austenitic stainless steels have shown that nitrogen effects are essentially equal and additive to those of carbon (both interstitial elements); increasing interstitial content. $(C+N)$ increases strength properties and decreases ductility; mechanical properties are stabilized at interstitial concentrations 
$(C+N)$ above $\sim 0.13$ weight percent; and the effect of interstitial concentration on mechanical properties is minimized at temperatures above $1100^{\circ} \mathrm{F}$ $\left(593^{\circ} \mathrm{C}\right)[8,9]$. Results of these studies also indicate the nitrogen contents of the piping material could be expected to increase the room temperature ultimate and $0.2 \%$ yield strengths by $5-10 \mathrm{Ksi}(34.5-69 \mathrm{MPa})$ and to decrease total elongation by $\sim 5$ percent as compared to average $376 \mathrm{H}$ stainless steel. Also, increasing test temperatures above $1100^{\circ} \mathrm{F}\left(593^{\circ} \mathrm{C}\right)$ would result in tensile properties of pipe material converging with mean behavior. Results of the present study are in agreement with this behavior (Figure 2).

\section{Strain Rate Effects}

The effect of strain rate on the strength of $316 \mathrm{H}$ stainless steel piping material for temperatures of $900,1050,1200^{\circ} \mathrm{F}\left(482,566\right.$, and $\left.649^{\circ} \mathrm{C}\right)$ is presented in Figure 4 . For temperatures to $1050^{\circ} \mathrm{F}\left(566^{\circ} \mathrm{C}\right)$ the ultimate strength slightly decreases with increasing strain rate for all rates. At $1200^{\circ} \mathrm{F}\left(649^{\circ} \mathrm{C}\right)$ the strength initially rapidly increases with strain rate to a rate of $\sim 3 \times 10^{-3} \mathrm{in} / \mathrm{in} / \mathrm{sec}$ and then remains constant with increasing rate. The $0.2 \%$ yield strength slightly increases with strain rate for all test temperatures (Figure 4). Data presented in this figure represent the average results from all three heats of piping material.

The total and uniform elongation of the subject material is affected by strain rate for temperatures of 900,1050 and $1200^{\circ} \mathrm{F}\left(482,566\right.$, and $\left.649^{\circ} \mathrm{C}\right)$ as shown in Figure 5. At all three temperatures total elongation decreases with increasing strain rate (from $\sim 47 \%$ to $38 \%$ ). Uniform elongation also de creases with increasing strain rate for temperatures of 900 and $1050^{\circ} \mathrm{F}$ (482 and $\left.566^{\circ} \mathrm{C}\right)$. At $1200^{\circ} \mathrm{F}\left(649^{\circ} \mathrm{C}\right)$ uniform elongation remains essentially constant over the strain rate range of this study. As with the strength proper- 
ties, data presented in this figure were obtained from all material heats.

\section{Creep-Rupture Properties}

Creep rupture tests were performed on the subject material at test temperatures of 1050,1200 and $1400^{\circ} \mathrm{F}\left(566,649\right.$, and $\left.760^{\circ} \mathrm{C}\right)$ and at stress levels to produce ruptures in times from 10 to 2500 hours. As with the tensile properties, the majority of tests were performed on heat 55320 . Results of the creep rupture tests are illustrated in Figures 6-9.

The stress dependence on rupture life for the test material and temperatures of 1050,1200 , and $1400^{\circ} \mathrm{F}\left(566,649\right.$, and $\left.760^{\circ} \mathrm{C}\right)$ is presented in Figure 6. At all three test temperatures a linear dependence is noted. Data are included in the figure for the three heats of material and for a few tests on transverse oriented (circumferencial) specimens from Heat 55320. No significant heat-to-heat or orientation effect is observed. Similar behavior is observed in Figure 7 where $\log$ stress versus 109 minimum creep rate is presented.

The ductility (elongation at rupture) of the subject materials for the various temperatures and rupture lives is illustrated in Figure 8 . At $1050^{\circ} \mathrm{F}$ $\left(566^{\circ} \mathrm{C}\right)$ total elongation slightly decreases with increasing rupture life. At the higher test temperatures $\left(1200\right.$ and $1400^{\circ} \mathrm{F}$ ) an opposite trend is observed since ductility increases with rupture life. All three heats of material exhibit similar ductility over the temperature-rupture time range of this study. Also, little effect of specimen orientation is observed.

To provide an indication of the quality of the piping material stressrupture properties were compared to those obtained on other heats of material (ASME Code Case 1592). As shown in Figure 9, the piping material exhibits higher stress-rupture behavior for temperatures of 1050 and $1200^{\circ} \mathrm{F}$ (566 and 
$\left.649^{\circ} \mathrm{C}\right)$ and slightly lower behavior at a temperature of $1400^{\circ} \mathrm{F}\left(760^{\circ} \mathrm{C}\right)$. The stress dependence on rupture life for the piping material parallels that of ASME Code Case 1592 for all three test temperatures. A direct comparison between the stress-rupture ductility of the piping material and that of other Type 316 stainless steel cannot be made since different specimen geometries and gauge lengths were employed in the previous studies resulting in large variations in ductility. However, inspection of creeprupture ductility data [7] indicates the piping material has greater ductility than the average of the other materials.

\section{Fatigue-Crack Growth Properties}

Results of fatigue-crack growth testing at $1000^{\circ} \mathrm{F}\left(538^{\circ} \mathrm{C}\right)$ on the piping material have been reported in detail by James [4] and are summarized in Figure 10. Data presented in these figures indicate crack orientation (axial or circumferential) has little effect on growth rate and piping material exhibits growth rates almost identical to other heats of Type 316 stainless steel. Also, thermal aging for 6000 hours at $1000^{\circ} \mathrm{F}\left(538^{\circ} \mathrm{C}\right)$ does not alter the fatigue crack growth rate of the test material.

\section{Thermal Aging Effects}

The effect of thermal aging on the tensile properties of the piping material was determined to insure material behavior consistent with that previously reported [10] for Type 316 stainless steel. Aging was performed in static sodium at $1050^{\circ} \mathrm{F}\left(566^{\circ} \mathrm{C}\right)$. Exposure durations ranged to 10,000 hours.

The effect of exposure at $1050^{\circ} \mathrm{F}\left(566^{\circ} \mathrm{C}\right)$ on the room temperature and $1050^{\circ} \mathrm{F}\left(566^{\circ} \mathrm{C}\right)$ tensile properties of the pipe material is illustrated in Figure 11. Test data presented in the figure are for exposures to 4000 
hours; the 10,000 hour data are extrapolated results based on similar thermal aging of an additional heat of Type 316 stainless steel [5]. As shown in the figure, the room temperature $0.2 \%$ yield and ultimate strengths of the test material are unchanged by exposure at $1050^{\circ} \mathrm{F}\left(566^{\circ} \mathrm{C}\right)$ for durations to 10,000 hours. For the same exposure and test conditions total elongation is slightly reduced (from $\sim 55$ to $48 \%$ ) with exposure time. Results from tests at $1050^{\circ} \mathrm{F}$ $\left(566^{\circ} \mathrm{C}\right)$ show that the ultimate strength and total elongation slightly decreases and the $0.2 \%$ yield strength remains constant with exposure time. Both the room temperature and $1050^{\circ} \mathrm{F}\left(566^{\circ} \mathrm{C}\right)$ results are in agreement with those reported by Blumberg [10].

\section{DISCUSSION}

The elevated temperature deformation behavior of Type 316 stainless steel has been extensively studied [11-15]. Although these studies have been performed at a variety of test conditions, no detailed description of the effect of strain rate and temperature on properties has been obtained. In the present study a variety of test techniques were employed which provided a detailed description of flow behavior over wide ranges of temperature and strain rate. Figure 12 presents the completed description where the elevated temperature ultimate strength of the test material is plotted versus strain rate. Data from creep-rupture tests were included by using the initial speci.. men stress and associated minimurn creep rate.

As shown in the figure, deformation is characterized by two distinct linear relationships. At all strain rates at $900^{\circ} \mathrm{F}\left(482^{\circ} \mathrm{C}\right)$ and the higher strain rates at 1050,1200 , and $1400^{\circ} \mathrm{F}\left(566,649\right.$, and $\left.760^{\circ} \mathrm{C}\right)$ the strength slightly decreases or remains constant with increasing strain rate. This decrease which has been previously observed in Type 304 stainless steel [16] 
is the result of the time and temperature-dependent effects of dynamic strain aging and adiabatic heating.

Dynamic strain aging is characterized by serrated stress-strain curves and results from dislocation interactions with interstitial carbon and nitrogen atoms [13-15]. Its influence on tensile behavior is to enhance the strain hardening ability of the material resulting in increased strength and ducti1ity. Since the materials used in this study had a high nitrogen content (see Table 1), dynamic strain aging would be expected to exhibit a pronounced influence on deformation behavior as was observed in the autographic test records. Increasing strain rate would be expected to retard dynamic strain aging resulting in decreased strength as observed in Figure 12.

Deformation at 1050,1200 , and $1400^{\circ} \mathrm{F}\left(566,649\right.$, and $\left.760^{\circ} \mathrm{C}\right)$ and $10 \mathrm{w}$ strain rates results in large increases in strength with increasing strain rate. In this region thermally activated mechanisms (creep) control deformation and mechanical properties are very dependent on test temperature and strain rate. At the lower test rates Fahr [12] has shown that dynamic strain aging does not greatly infiuence properties. This minimum influence results because the temperature is high enough and strain rate low enough to allow carbon and nitrogen atoms to migrate along with dislocations. As strain rate increases the carbon and nitrogen atoms retard dislocation movement resulting in increased strain hardening (strain aging). The maximum effect of strain aging (as indicated by magnitude of serrations) on properties is believed to occur at the intersection of the two linear relationships (Figure 12). Thus, at the high temperature $\left(\geq 1050^{\circ} \mathrm{F}\right)$ bulk diffusion is retarded and dynamic strain aging enhanced by increasing strain rate resulting in observed behavior. 


\section{SUMMARY AND CONCLUSIONS}

The tensile, creep-rupture, high strain rate, and fatigue-crack growth properties of FFTF primary outlet piping have been determined. This characterization has shown that mechanical properties of the roll extruded piping compares favorably with properties obtained on other product forms. Results are summarized as follows:

- Mechanical properties and chemical compositions were essentially identical for the three heats of piping material studied.

- Tensile and creep-rupture properties exceeded values on which allowable stresses for ASME Code Case 1592 (Nuclear Components in Elevated Temperatures Service) were based.

- Tensile properties were insensitive to strain rate of temperatures to $900^{\circ} \mathrm{F}$. At temperatures of $1050^{\circ} \mathrm{F}$ and above significant increases in strength and ductility were observed with increasing strain rate.

- Fatigue-crack propagation properties were comparable to results obtained on plate material. No differences in crack-growth rates were found between axial and circumferential orientations.

- Mechanical properties were essentially unchanged by thermal aging at $1050^{\circ} \mathrm{F}$. 


\section{ACKNOWLEDGEMENTS}

This paper is based upon work performed under United States Atomic Energy Cormission Contract AT(45-1)-2170 with the Westinghouse Hanford Company, a subsidiary of Westinghouse Electric Corporation.

The authors acknowledge the efforts of T. C. Berry, R. G. Bentley, and G. L. Hood in obtaining the test data used for this paper. 


\section{REFERENCES}

1. Steichen, J. M., "FFTF Primary Piping Fabrication Comparison," Westinghouse Hanford Company Report HEDL-TiME 72-133, October 1972.

2. Moen, R. A., O'Keefe, D. P., Irvin, J. E., and Tobin, J. C., "Specifying and Manufacturing Piping for the Fast Flux Test Facility, " 1974 ASME Congress on Pressure Vessels and Piping, Miami Beach, June 24-25, 1974.

3. "Plate-Strain Fracture Toughness of Metallic Materials," Specification E 399-72, 1972 Annual Book of ASTM Standards, Part 31, pp. 955-974, American Society for Testing and Materials, 1972.

4. James, L. A., "Fatigue-Crack Propagation Behavior of FTR Outlet Piping Material at $1000^{\circ} \mathrm{F}$," Westinghouse Hanford Company Report HEDL-TME 74-48, August, 1974.

5. Steichen, J. M., "Mechanical Properties of FFTF Primary Outlet Piping," Westinghouse Hanford Company Report HEDL-TME 75-15, January 1975.

6. Smith, G. V., "An Evaluation of the Yield, Tensile, Creep, and Rupture Strengths of Wrought $304,316,321$, and 347 Stainless Steel at Elevated Temperatures," ASTM Data Series DS5-S2, American Society for Testing and Materials, 1969.

7. Smith, G. V., "The Elevated-Temperature Properties of Stainless Stee1," ASTM Data Series DS5-S1, American Society for Testing and Materials, 1965.

8. Soo, P., and Horton, W. H., "The Effect of Carbon and Nitrogen on the Short-Term Tensile Behavior of Solution-Treated Types 304 and 316 Stainless Stee1," Westinghouse Electric Corporation Report WARU-NA-3045-2, July, 1973.

9. Gunia, R. B., and Woodrow, G. R., "Nitrogen Improves Engineering Properties of Chromium-Nickel Stainless Steels," Journal of Materials, Vol. 5, No. 2, 1970, pp. $413-430$.

10. Blumberg, H. S., "Type 316 for Elevated-Temperature Power-Plant Applications," Climax Molybdenum Company Report, 1965.

11. Garofa10, F., Whitmore, R. W., Domis, W. F., ard Von Gemrigen, F., "Creep and Creep-Rupture Relaitionships in an Austenitic Stainless Stee1," Transactions AIIAE, Vo1. 221, Apri1, 1961, Fp. 310-319.

12. Fahr, D., "Analysis of Stress-Strain 3ehavior of Type 316 Stainiess Stee1," Cak Ridge Niational Laboratory Report, CRiNL-TM-4292, November, 1973.

13. Barnisy, 3. T., "Effect of Strain Aging on Creep of an AISI 37E fustenitic Stainless Steel,": Jcurnai of the Iron and Steal institute, Vol. 207, No. 1, January, 1956, pp. 23-2\%. 
14. Morris, J. G., "Dynamic Strain Aging in a Ti-Modified 316 Stainless Stee1," Materials Science and Engineering, Vo7. 7, 1971, pp. 296-301.

15. Barnby, J. T., "Effect of Strain Aging on the High-Temperature Tensile Properties of an AISI 316 Austenitic Stainless Steel," Journal of the Iron and Steel Institute, Vo1. 203, Apri1, 1965, pp. 293-397.

16. Steichen, J. M., "High Strain Rate Tensile Properties of AISI Type 304 Stainless Steel," Journal of Engineering Materials and Technology,

Vo1. 95, Series H, No. 3, JuTy, 1973, pp. 182-185. 


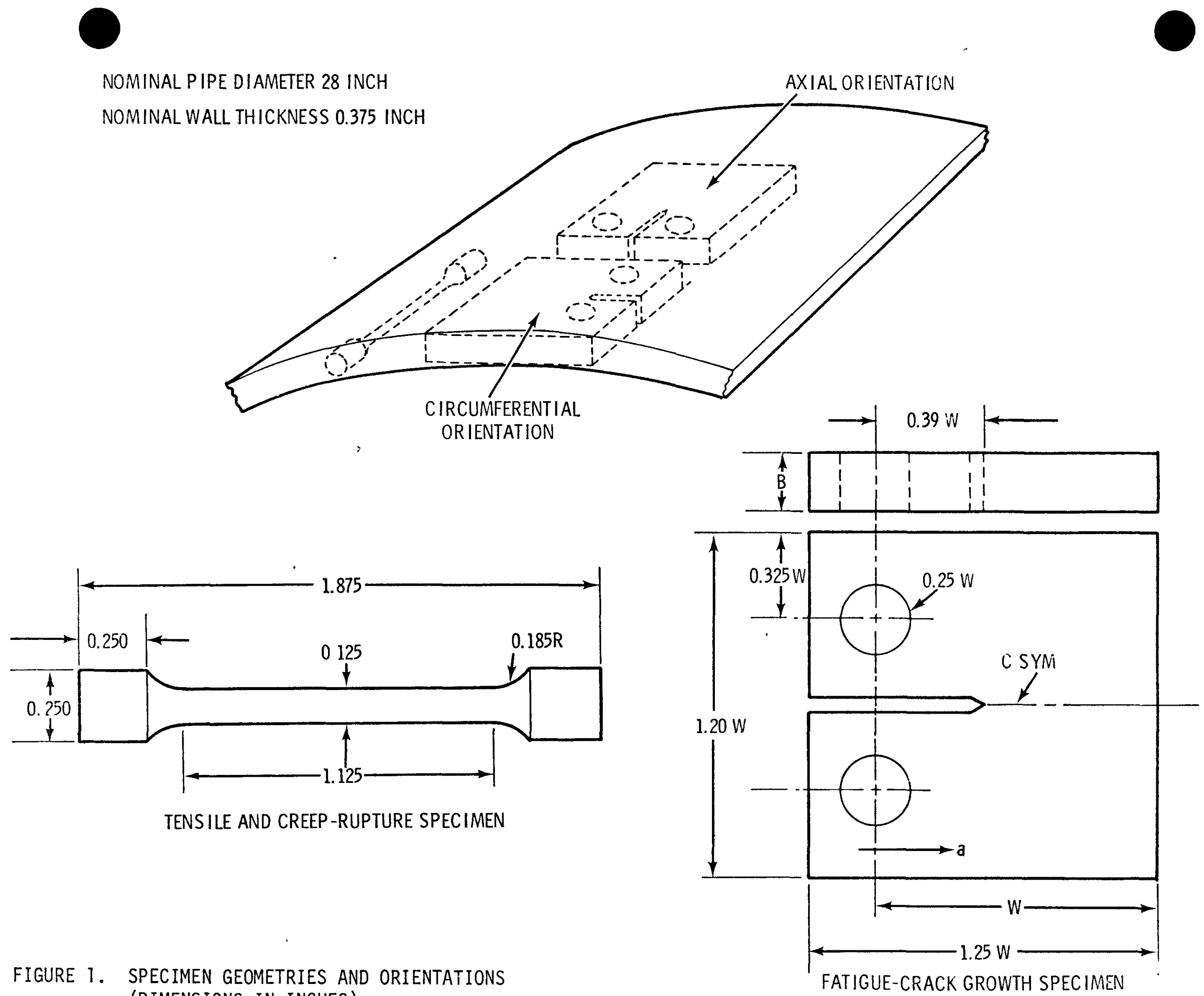




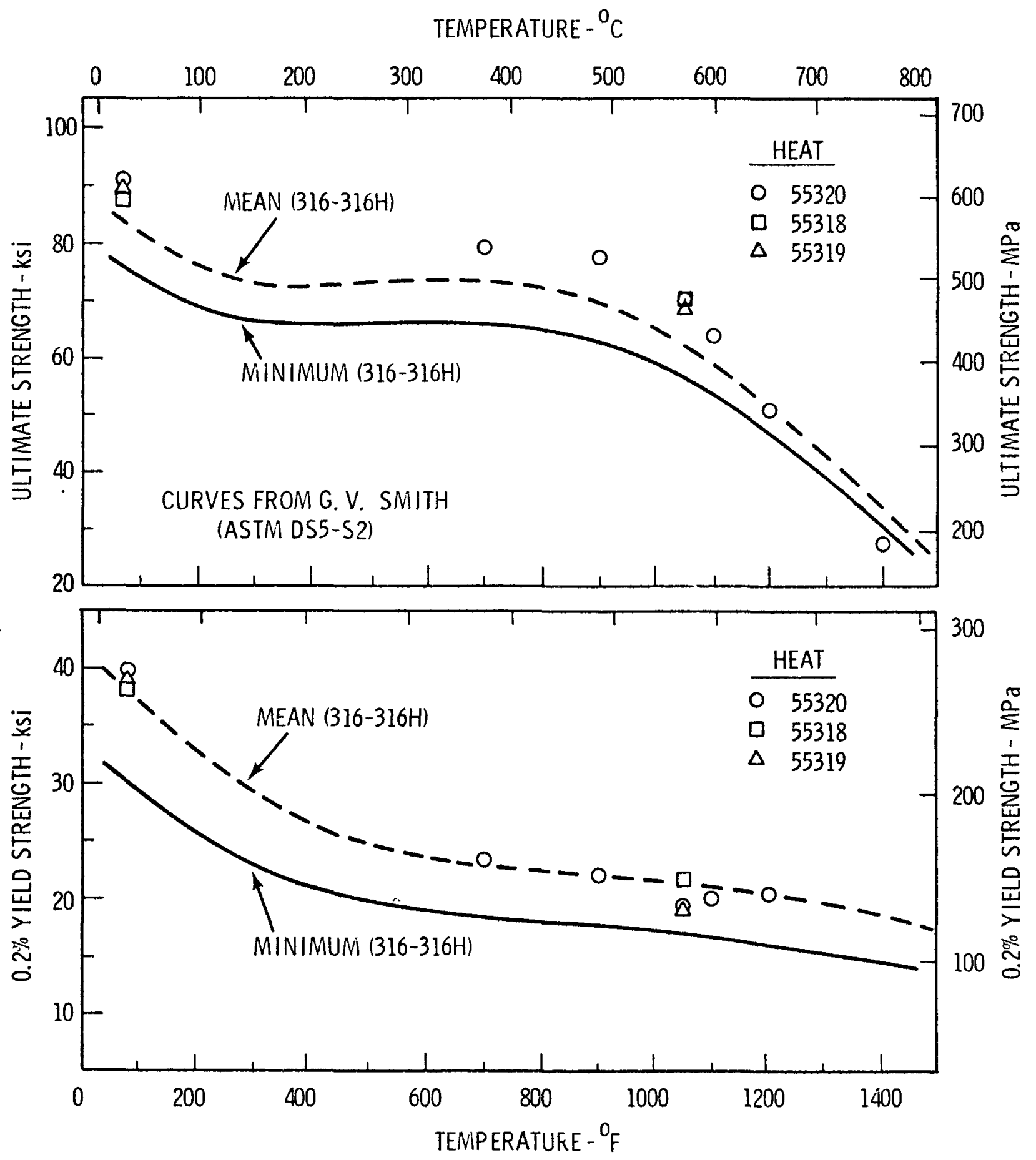

FIGURE 2. TEMPERATURE DEPENDENCE OF STRENGTH OF TYPE 316H STAINLESS STEEL PIPING MATERIAL. 


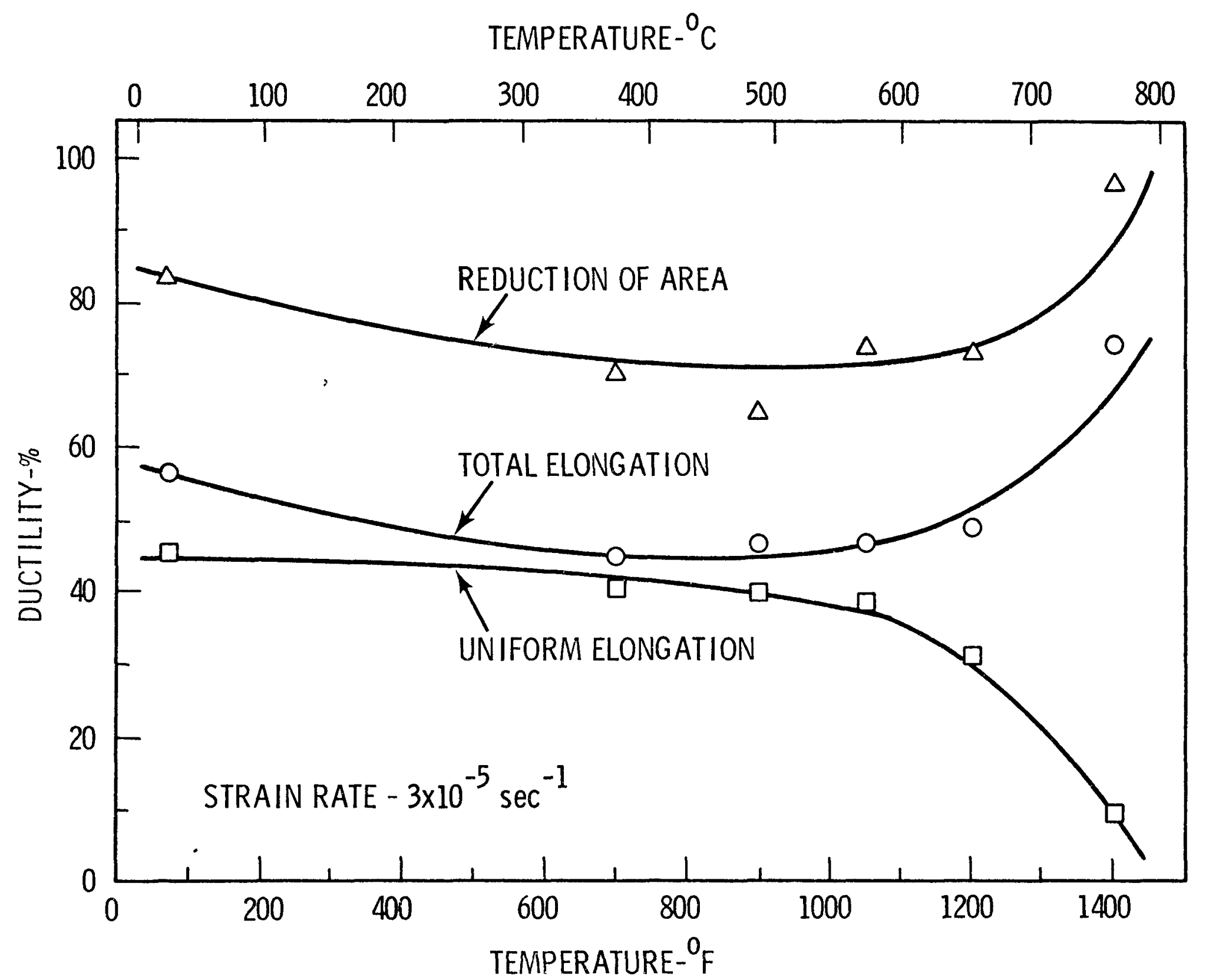

FIGURE 3. TEMPERATURE DEPENDENCE OF DUCTILITY OF TYFE 316H STAINLESS STEEL PIPING MATERIAL. 


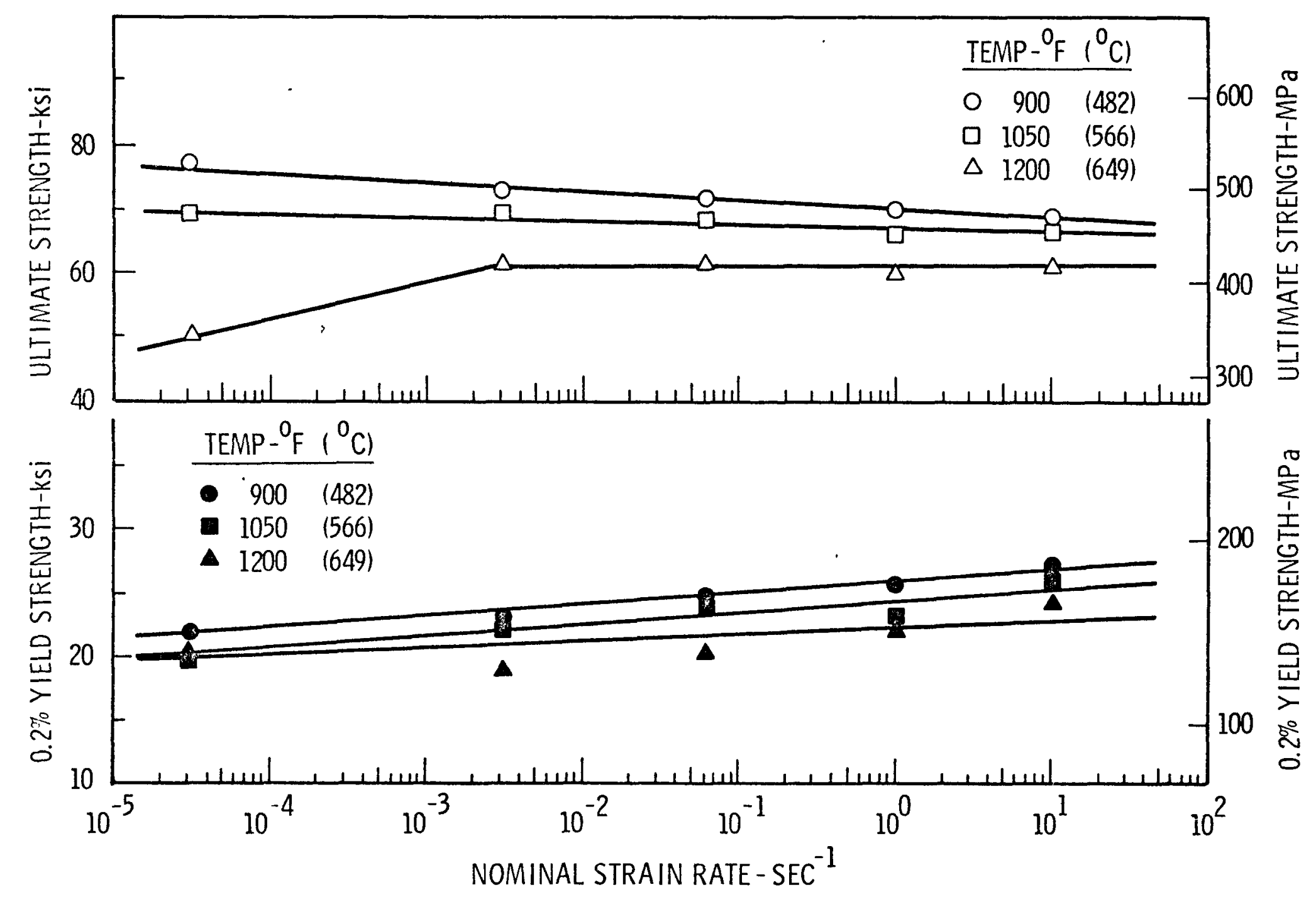

FIGURE 4. EFFECT OF STRAIN RATE AND TEMPERATURE ON THE STRENGTH OF TYPE 316H STAINLESS STEEL PIPING MATERIAL. 

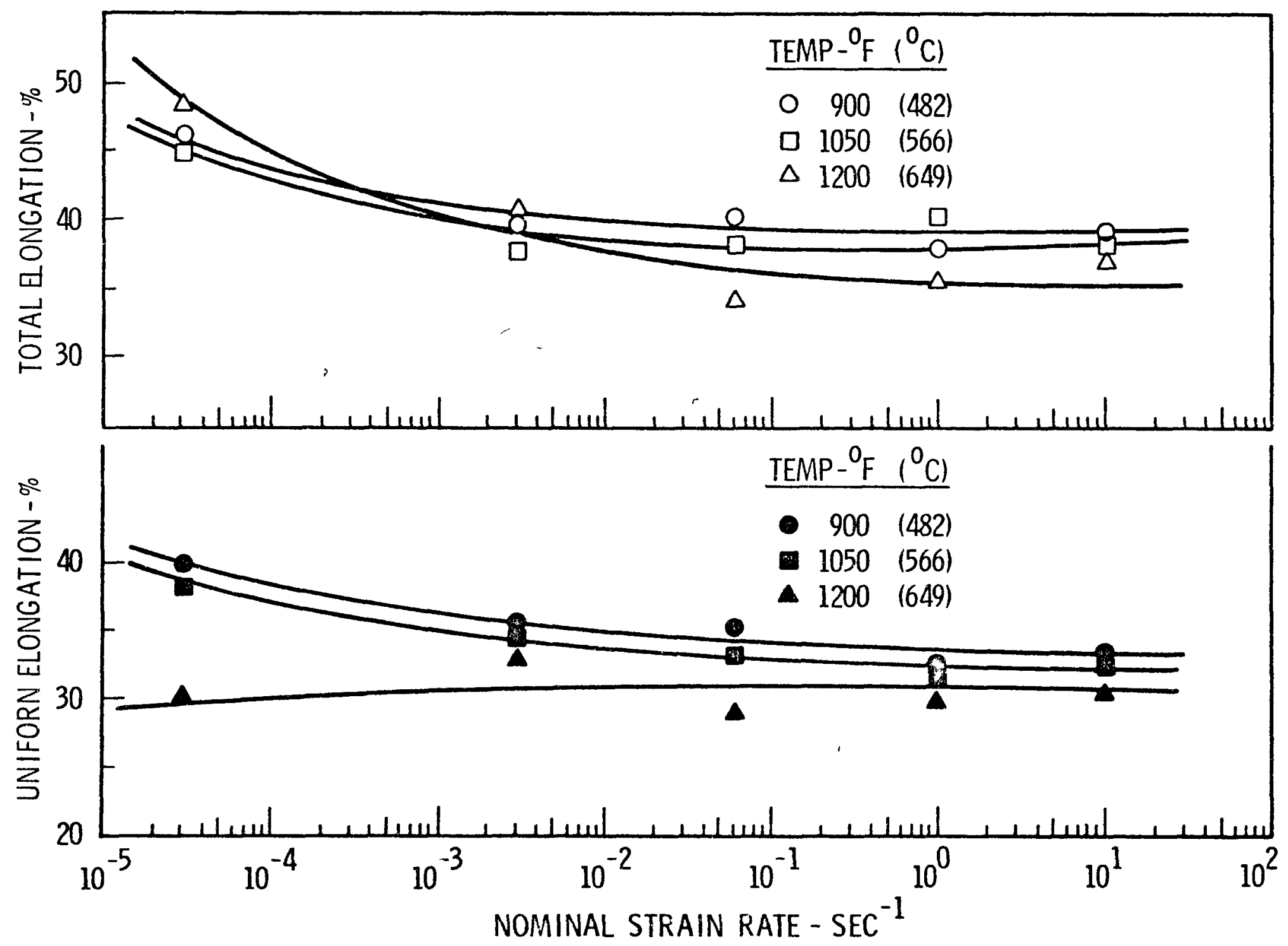

FIGURE 5. EFFECT OF STRAIN RATE AND TEMPERATURE ON THE DUCTILITY OF TYPE 316H STAINLESS STEEL PIPING MATERIAL. 


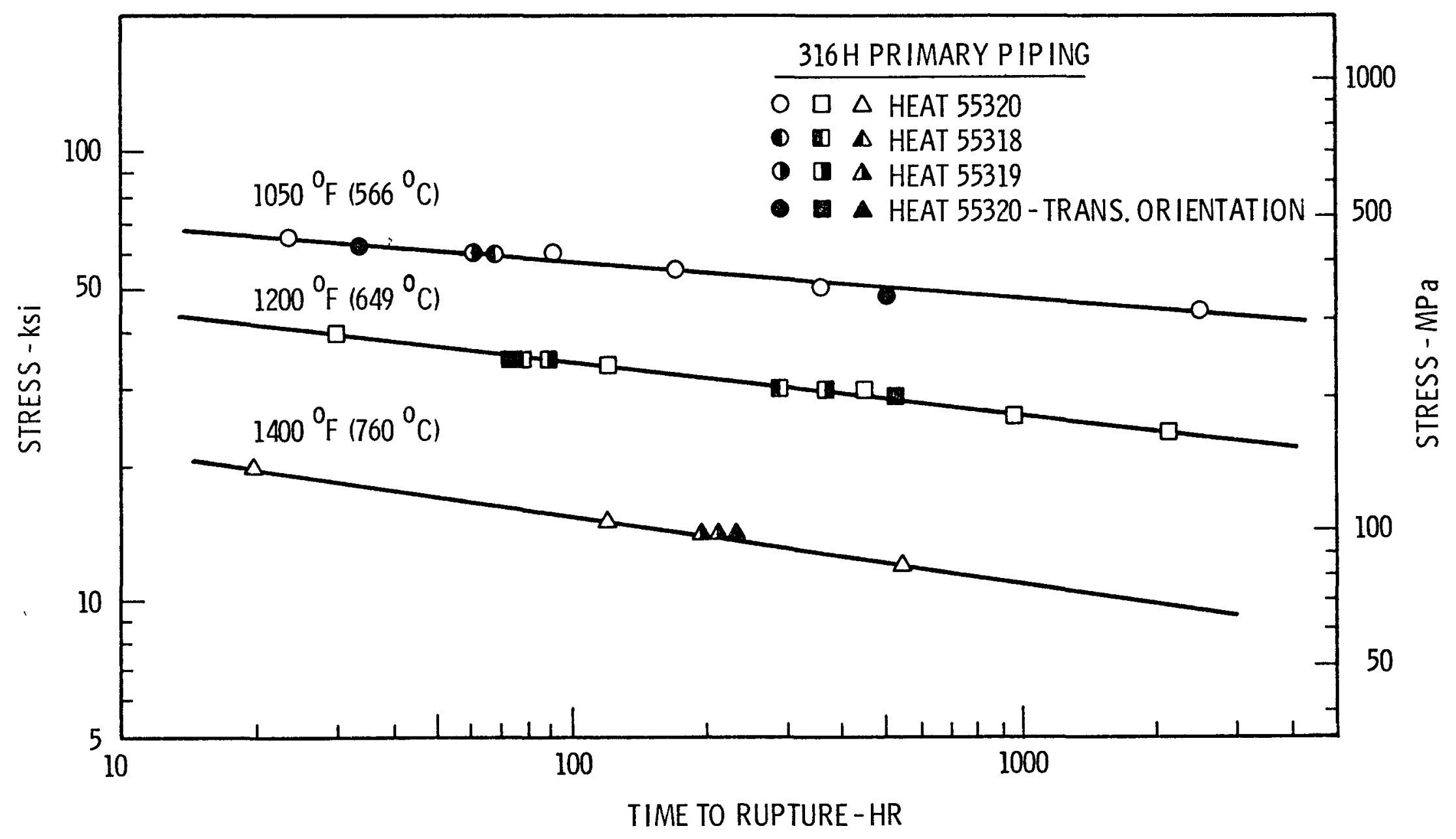

FIGURE 6. STRESS-RUPTURE BEHAVIOR OF TYPE 316H STAINLESS STEEL PIPING MATERIAL. 


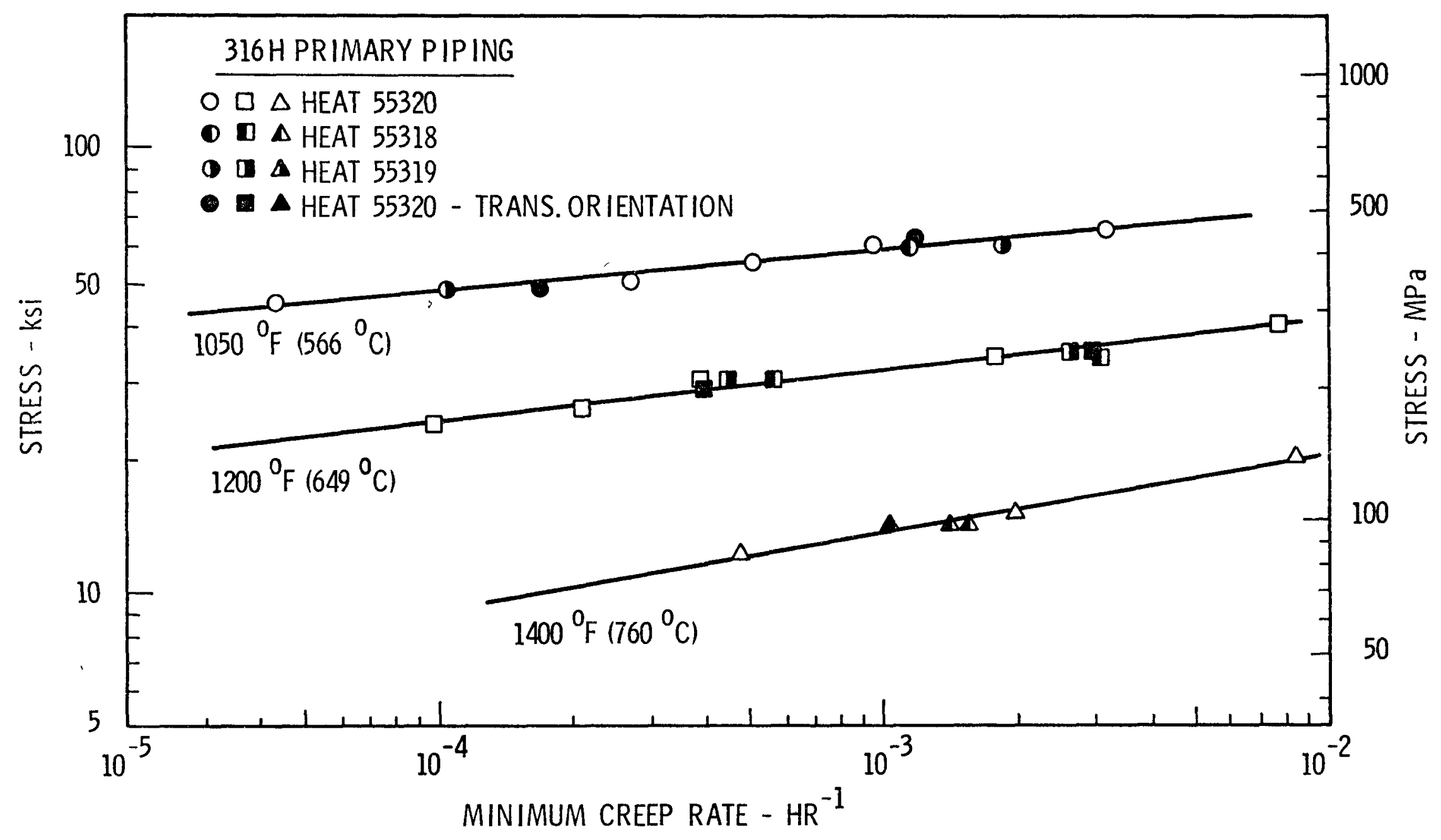

FIGURE 7. STRESS VERSUS MINIMUM CREEP RATE FOR TYPE 316H STAINLESS STEEL PIPING MATERIAL. 


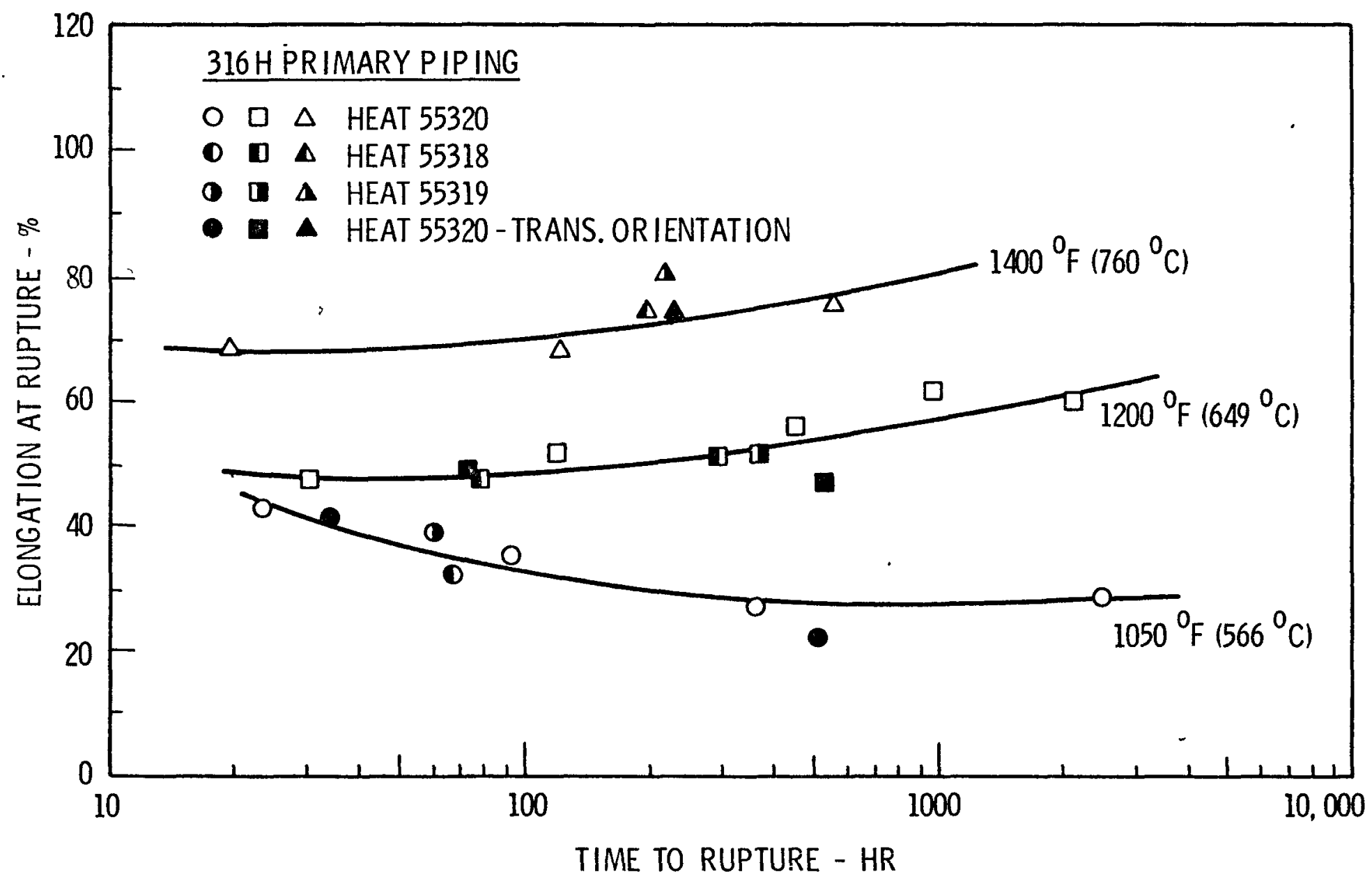

FIGURE 8. RUPTURE DUCTILITY OF TYPE 316H STAINLESS STEEL PIPING MATERIAL. 


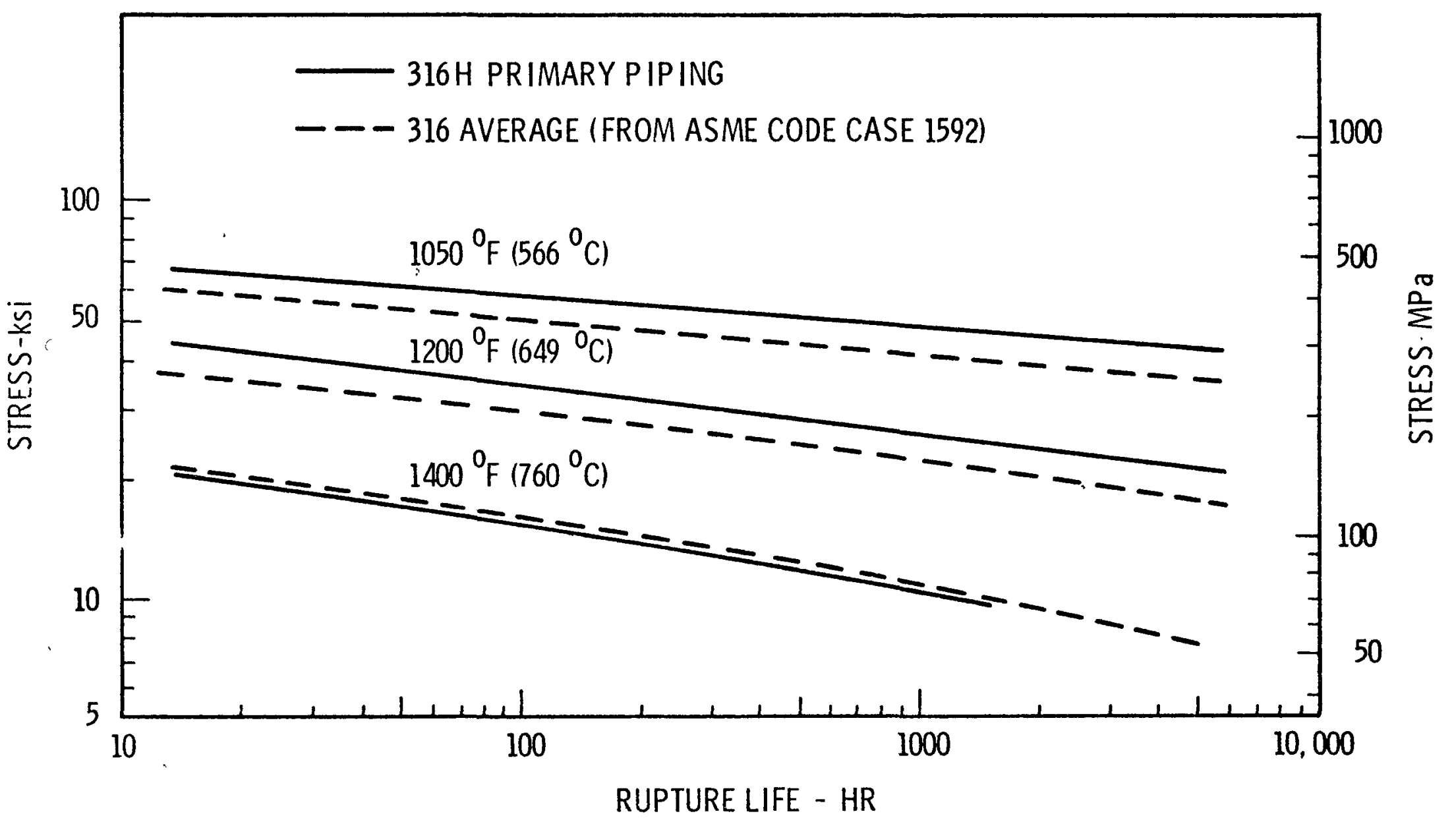

FIGURE 9. COMPARISON OF STRESS RUPTURE PROPERTIES TO ASME CODE. 


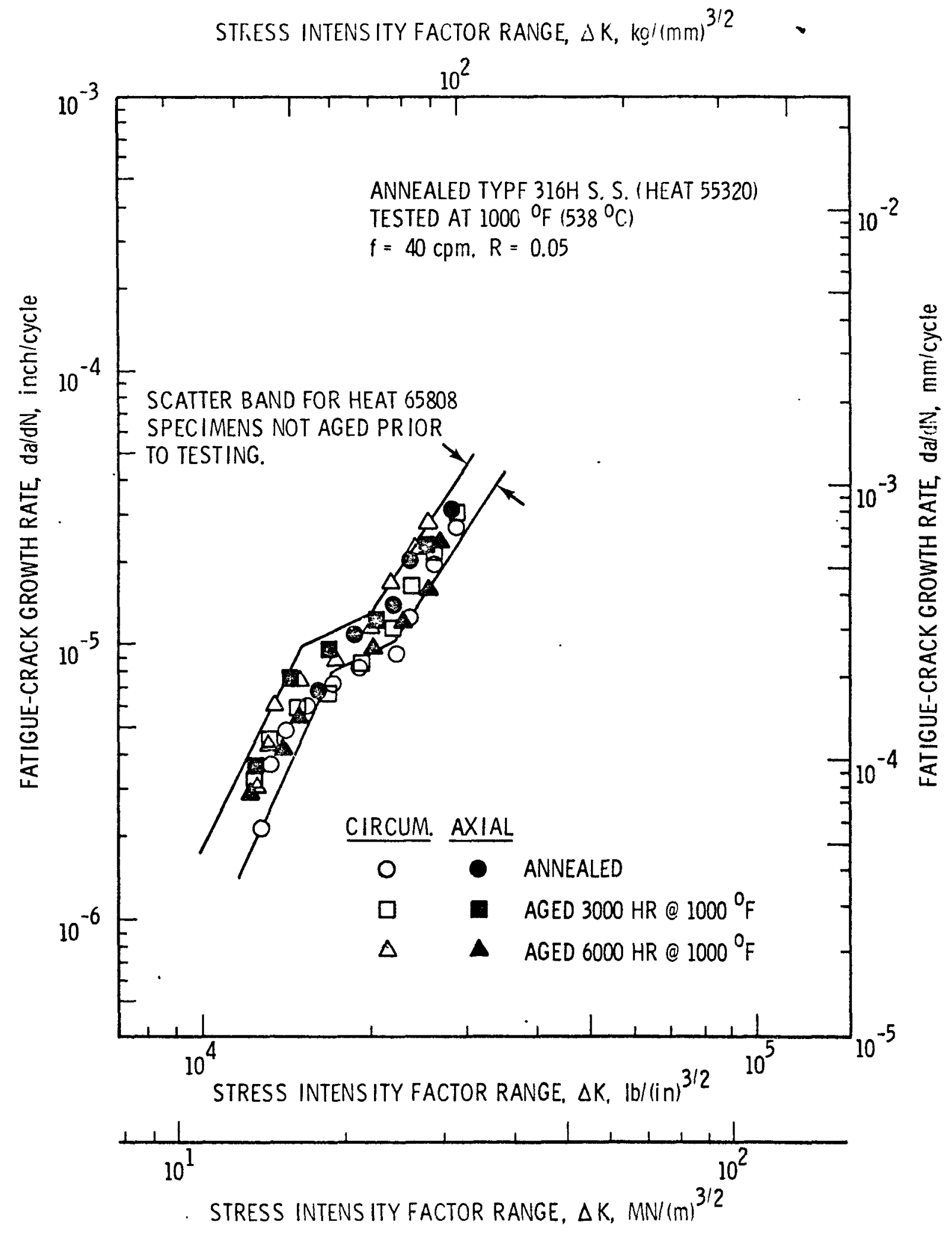

FIGURE 10. FATIGUE-CRACK GROWTH BEHAVIOR OF TYPE 316H STAINLESS STEEL PIPING MATERIAL. 

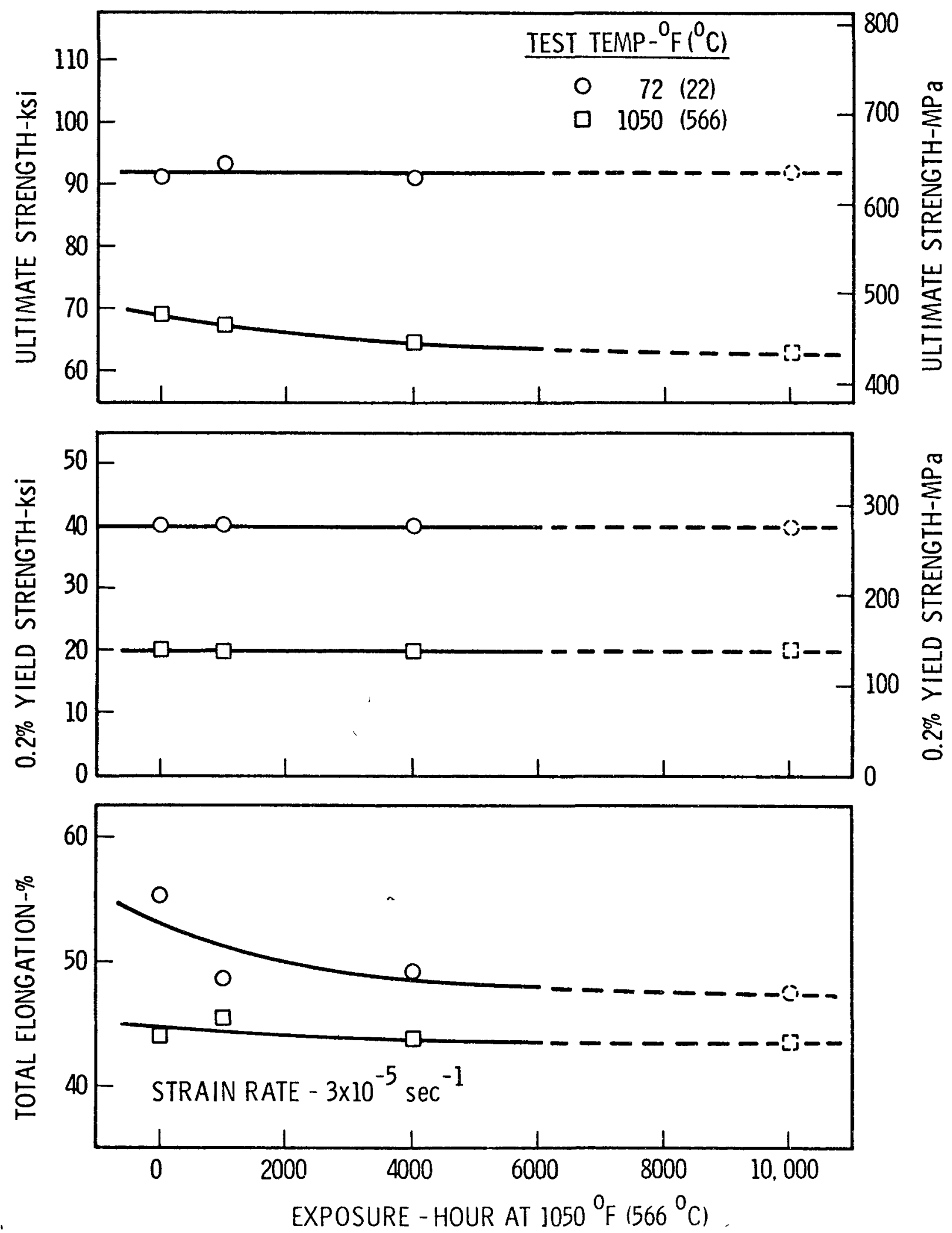

FIGURE 11. TENSILE PROPERTIES OF THERMALLY AGED TYPE 316H STAINLESS STEEL PIPING MATERIAL. 


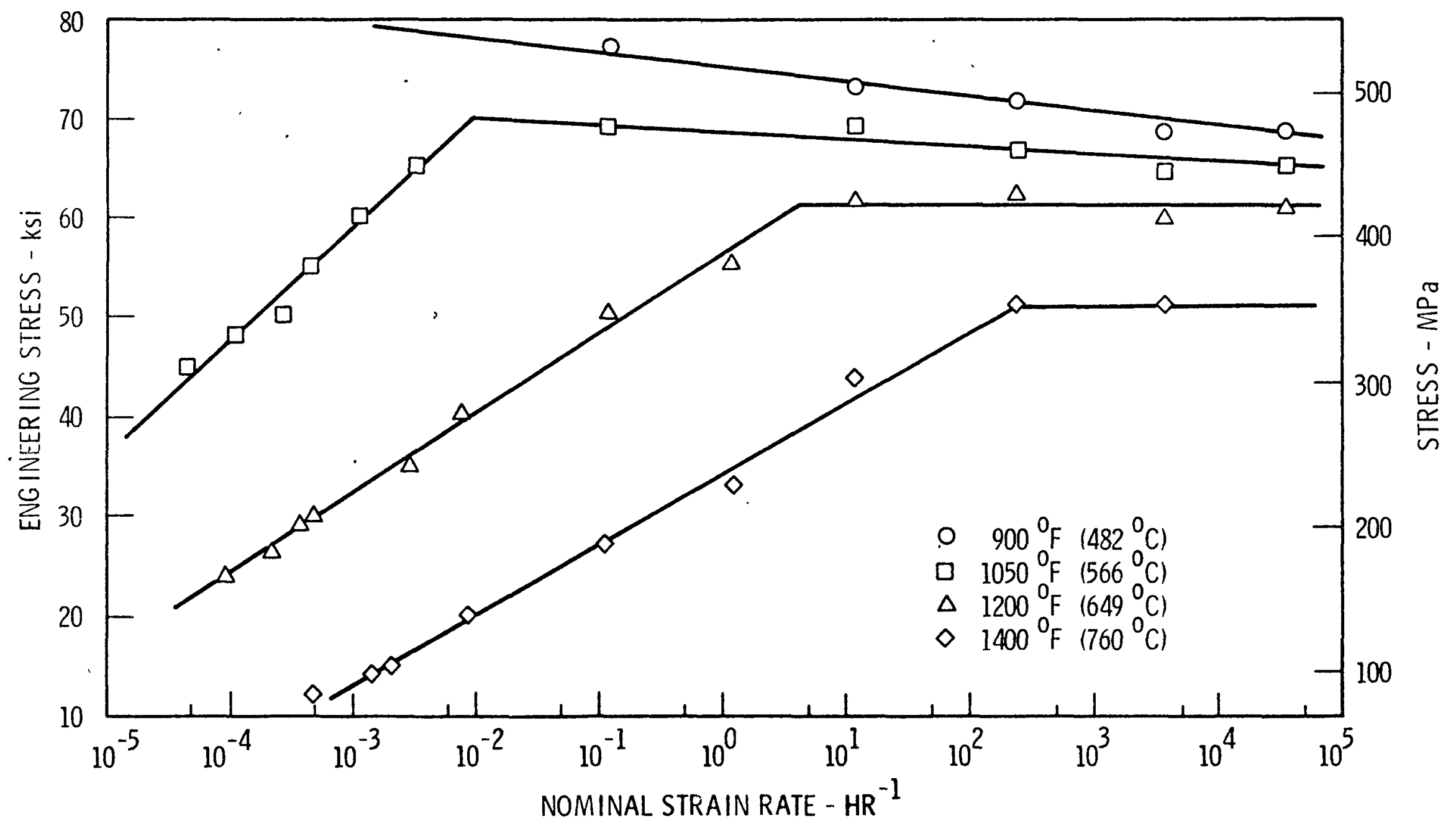

FIGURE 12. STRAIN RATE AND TEMPERATURE DEPENDENCE OF THE STRENGTH OF TYPE 316H STAINLESS STEEL . PIPING MATERIAL. 